\title{
Nuclear Medicine at the Hammersmith Hospital
}

\author{
Michael Peters
}

Nuclear medicine at the Hammersmith Hospital was established as a separate unit by Peter Lavender in the early seventies. It was called the Radioisotope Unit to distinguish it from the pre-existing Department of Medical Physics, headed by Harold Glass who was one of the early pioneers in medical radioisotope scanners [1]. As well as providing a clinical service, the unit, which only comprised two rooms, was active in clinical research complemented by the extensive academic activities of the MRC Cyclotron Unit. Two good examples of these activities that launched nuclear medicine at Hammersmith are firstly the development by Clark, Watson Fazio and Jones of $\mathrm{Kr}-81 \mathrm{~m}$ for ventilation and perfusion studies [2], and secondly, cell labelling.

$\mathrm{Kr}-81 \mathrm{~m}$ is a $13 \mathrm{~s}$ half-life radionuclide that is the metastable daughter of Rb-81, which has a half-life of $4.7 \mathrm{~h}$. To obtain $\mathrm{Kr}-81 \mathrm{~m}$ gas, oxygen is passed through the generator. There was an enthusiastic response to the generator across the UK, and, at one point, $\mathrm{Kr}-81 \mathrm{~m} / \mathrm{Tc}-99 \mathrm{~m}$ ventilation/perfusion imaging was the second most frequently performed imaging procedure in the UK after bone scanning. Whilst $\mathrm{Kr}-81 \mathrm{~m}$ remains the optimal ventilation agent for lung scanning, it is not so widely appreciated that Lavender and his colleagues also administered $\mathrm{Kr}-81$ in solution to measure tissue perfusion. To obtain $\mathrm{Kr}-81 \mathrm{~m}$ in solution, isotonic glucose is passed through the generator. For example, Harvey-Turner and Selwyn infused Kr-81m into the aortic root of dogs and continuously imaged regional changes in myocardial perfusion in response to transient coronary artery occlusion [3]. The distribution of pulmonary blood flow in humans was also imaged by continuous intravenous infusion [4]. Kr-81m was given both by inhalation and infusion to study ventilationperfusion ratios and regional lung function in adults [4, 5] and children [6], When combined with the longer half-life Kr-85 (a lung gas volume marker), regional lung

M. Peters

Department of Nuclear Medicine, Clinical and Laboratory Investigation, Brighton and Sussex Medical School, Brighton BN1 9PX, UK 

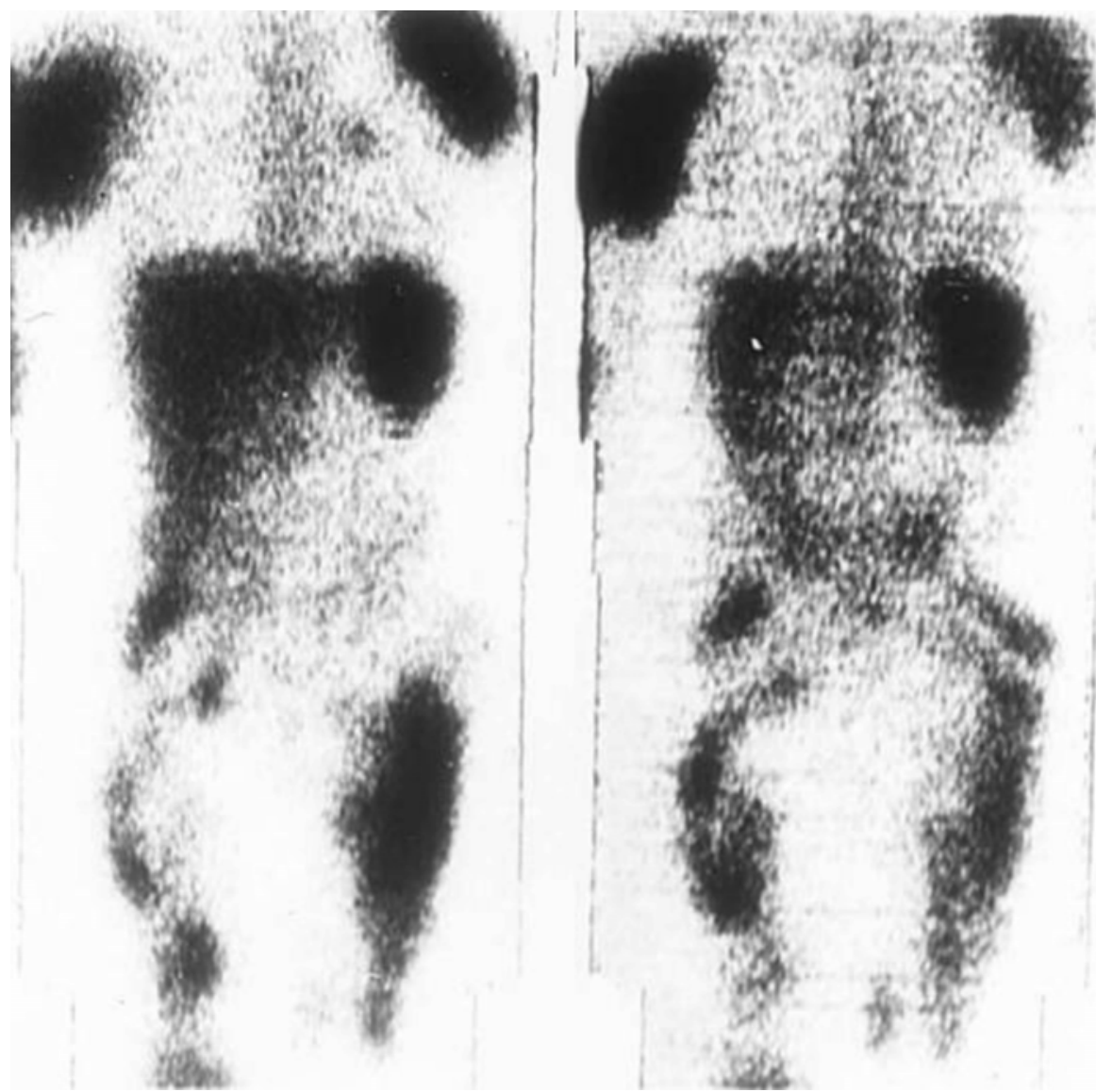

Fig. 12.1 A patient with multiple sites of sepsis imaged with In-111-labelled leucocytes (From Ref. [8])

function per unit volume could be assessed. Lavender used $\mathrm{Kr}-81 \mathrm{~m} / \mathrm{Tc}-99 \mathrm{~m}$ SPECT in the early eighties to study pulmonary physiology [7] but did not feel that it offered any great advantage over planar imaging for diagnosing pulmonary thromboembolic disease.

The second example of innovative collaboration between Hammersmith nuclear medicine and MRC Cyclotron Unit was the development of cell labelling by Thakur and McAfee. John McAfee came to the Hammersmith for a 6 month sabbatical with the specific aim of working with Matthew Thakur to develop cell labelling for clinical imaging. Cr-51 had already been developed for cell labelling but is not suitable for gamma camera imaging, only surface counting. Testing several combinations of lipophilic chelating agents and radiometals, Thakur and McAfee came up with In-111 and hydroxyquinoline (oxine). The first full paper on leucocyte scanning for sepsis, based on 15 patients, was published in 1977 ([8]; Fig. 12.1). 


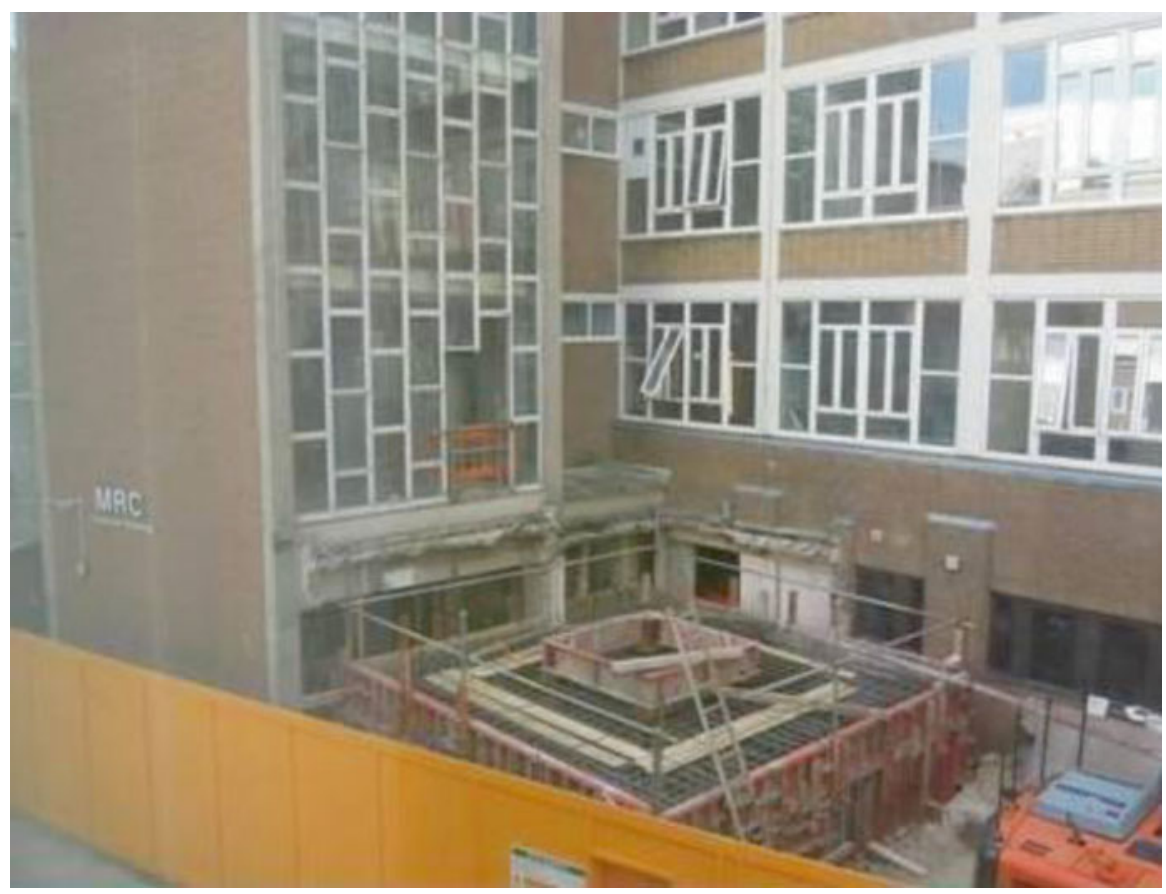

Fig. 12.2 The cyclotron being installed in the MRC building at the Hammersmith Hospital in 1956

There was great hope for performing labelled lymphocyte studies too, until it was soon found that lymphocytes are radio-sensitive and destroyed by labelling with amounts of In-111 required for imaging. I arrived at the Hammersmith in 1979 to undertake a 3-year Cancer Research Campaign-funded project on labelled lymphocytes but with this discovery quickly turned my attention to labelled leucocytes and platelets. In those days, Amersham International was not selling In-111-oxine, so it had to be prepared in-house (by a radio-chemist, Malcolm Kensett, in the MRC Cyclotron Unit). Once a patient had been identified, I would order the In-111-oxine, go to the MRC to collect it, take the patient's blood, go to the Haematology Isotope Unit to label it, then take it back to the Radioisotope Unit to inject it and image the patient. The Haematology isotope unit under the leadership of Mitchell Lewis, provided a tertiary service for ferrokinetics, using Fe-59 and Fe-52 (a positron emitter), and red cell survival and surface counting studies using Cr-51-labelled red cells. The unit also supported studies involving labelled cells, including In-111-labelled platelet kinetic studies by Klonikakis et al. [9], In-113m-labelled red cells and platelets, and studies on the clearance rates of labelled red cells modified by heating or antibody coating, undertaken by several workers from the Department of Medicine studying reticulo-endothelial (RE) function.

The Medical Research Council funded the building of a medical cyclotron on the Hammersmith site in 1954 (Fig. 12.2). This stimulated much research into 
cardiopulmonary physiology and neuro-pathophysiology in collaboration with the clinical staff of the Hospital. Pairs of scintillation detectors (front and back) were used first (with coincidence counting of positron emission), then planar gamma camera imaging, and finally positron emission tomography. The first studies were carried out in the late 1950s by West and his colleagues [10-12] using the shortlived positron emitting isotope, oxygen-15 (half life $2.1 \mathrm{~min}$ ) as $\mathrm{C}^{15} \mathrm{O}_{2}$ and $\mathrm{C}^{15} \mathrm{O}$. Lung water distribution was studied with $\mathrm{H}_{2}{ }^{15} \mathrm{O}[13,14]$, pulmonary perfusion with infused ${ }^{13} \mathrm{~N}_{2}$ in solution [15], pulmonary haemorrhage with inhaled ${ }^{11} \mathrm{CO}$ [16], and ventilation with neon-19 [17]. Rhodes and Hughes [18] summarized pulmonary studies using the positron camera. There was also much interest in studies of inflammatory conditions using F-18-fluorodeoxyglucose $\left({ }^{18} \mathrm{FDG}\right)[19,20]$, and in imaging beta-agonist receptors in the heart and lung [21, 22].

Research activity elsewhere in the MRC Cyclotron Unit included the development of ${ }^{18} \mathrm{FDG}$ for imaging the brain (Terry Jones and Richard Frackowiak) and myocardium. Camici et al. were one of the first groups to image Rb-82 uptake in the myocardium of patients with coronary disease and show increased FDG uptake in ischaemic regions [23].

Many pioneers in nuclear medicine worked at Hammersmith. One of the earliest was Charles Galasko who in bone scintigraphy showed in 1968 that 12 of 50 patients with apparently 'early' breast cancer on clinical, radiological and biochemical grounds had positive scintigraphy and developed metastatic disease in the first 5 years following mastectomy [24]. Joseph Pflug was a pioneer in lymphatic function studies and was one of the first to use lymphoscintigraphy. Aga Epenetos, an oncologist, was one of the first to develop radiolabelled monocloncal antibodies for imaging cancer. Having worked with Keith Britton at St Bartholomew's and Walter Bodmer from the then ICRF, Epenetos continued his work at the Hammersmith. Also collaborating with ICRF, Lavender used a very effective monoclonal antibody to the platelet fibrinogen receptor for imaging thrombus ([25]; Fig. 12.3).

Dominic Haskard came to Hammersmith from Guy's Hospital around 1990 and developed very effective monocloncal antibodies to vascular adhesion molecules for imaging inflammation [26]. Sadly, however, none of these labelled antibodies made it into regular nuclear medicine practice.

Having developed In-111-oxine cell labelling, workers at the Hammersmith, again in collaboration with the MRC Cyclotron Unit (Danpure and Osman), then explored other chelating agents and discovered tropolone [27], which, now that GE do not offer In-111-oxine, is the standard agent for In-111 cell labelling. We then went on to develop Tc-99m-HMPAO for leucocyte labelling [28]. Saverymuttu demonstrated the extraordinary ability of In-111 and Tc-99m-labelled leucocyte scintigraphy to quantify and image inflammatory bowel disease (Fig. 12.4) and published numerous papers on its applications in gastroenterology.

Other, generally unfunded work, on patient volunteers established the normal whole body kinetics and physiological margination sites of granulocytes, and, in particular, dismantled the erroneous notion that the vast majority of intravascular granulocytes are pooled in the lungs [29]. It was clearly demonstrated how in systemic inflammatory diseases, such as pancreatitis, IBD and vasculitis, circulating granulocytes become primed, lose deformability and undergo prolonged transit through the pulmonary vasculature. This is in contrast to hold-up in the lungs of 

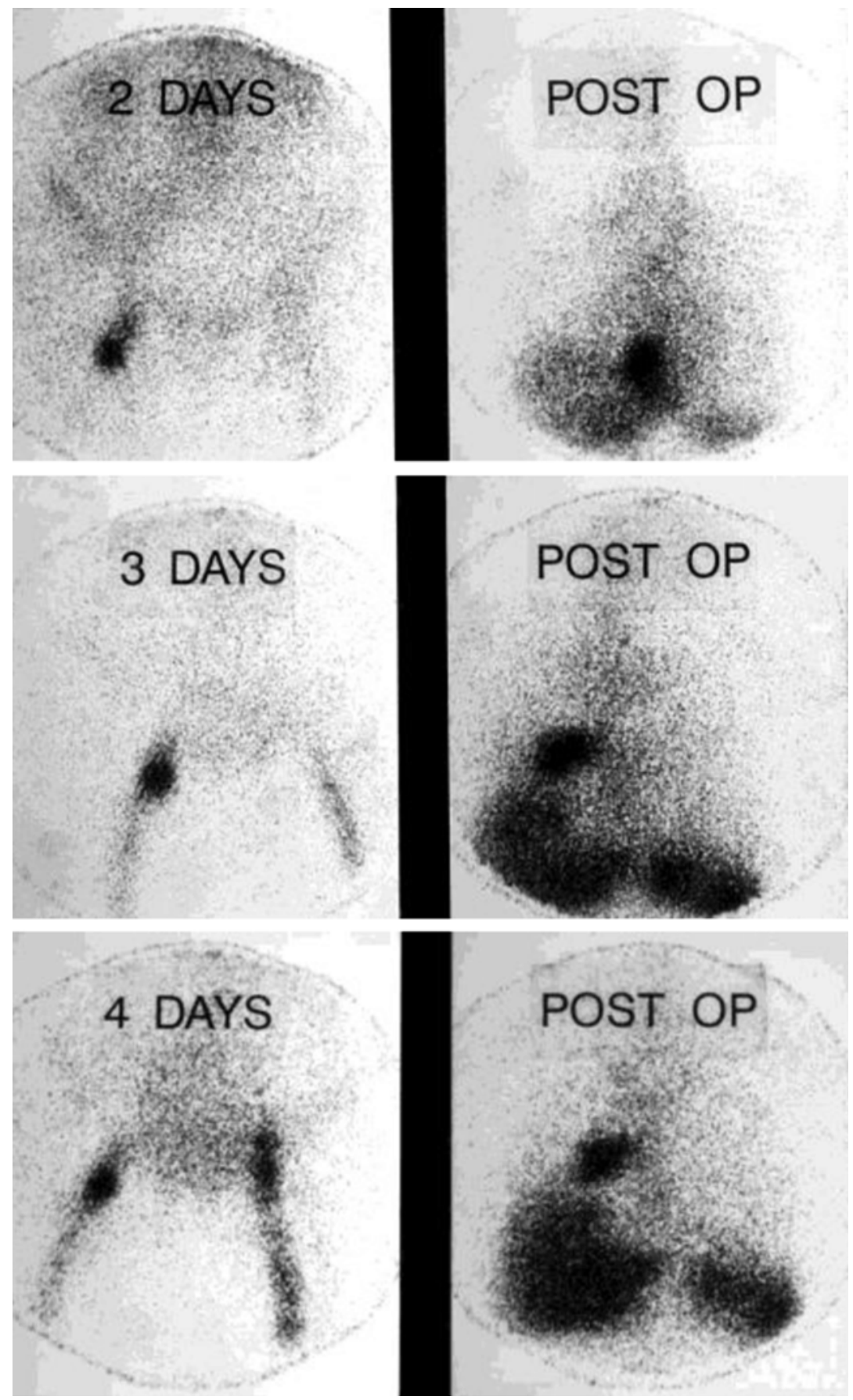

Fig. 12.3 Images in a patient who 2 (top panel), 3 (middle panel) and 4 (bottom panel) days before receiving a total hip replacement. The In-111-labelled antibody P256 was administered shortly after surgery. Note the development of thrombus in the femoral veins and the movement of an embolus from the right ventricle to right pulmonary artery (From Ref. [25]) 


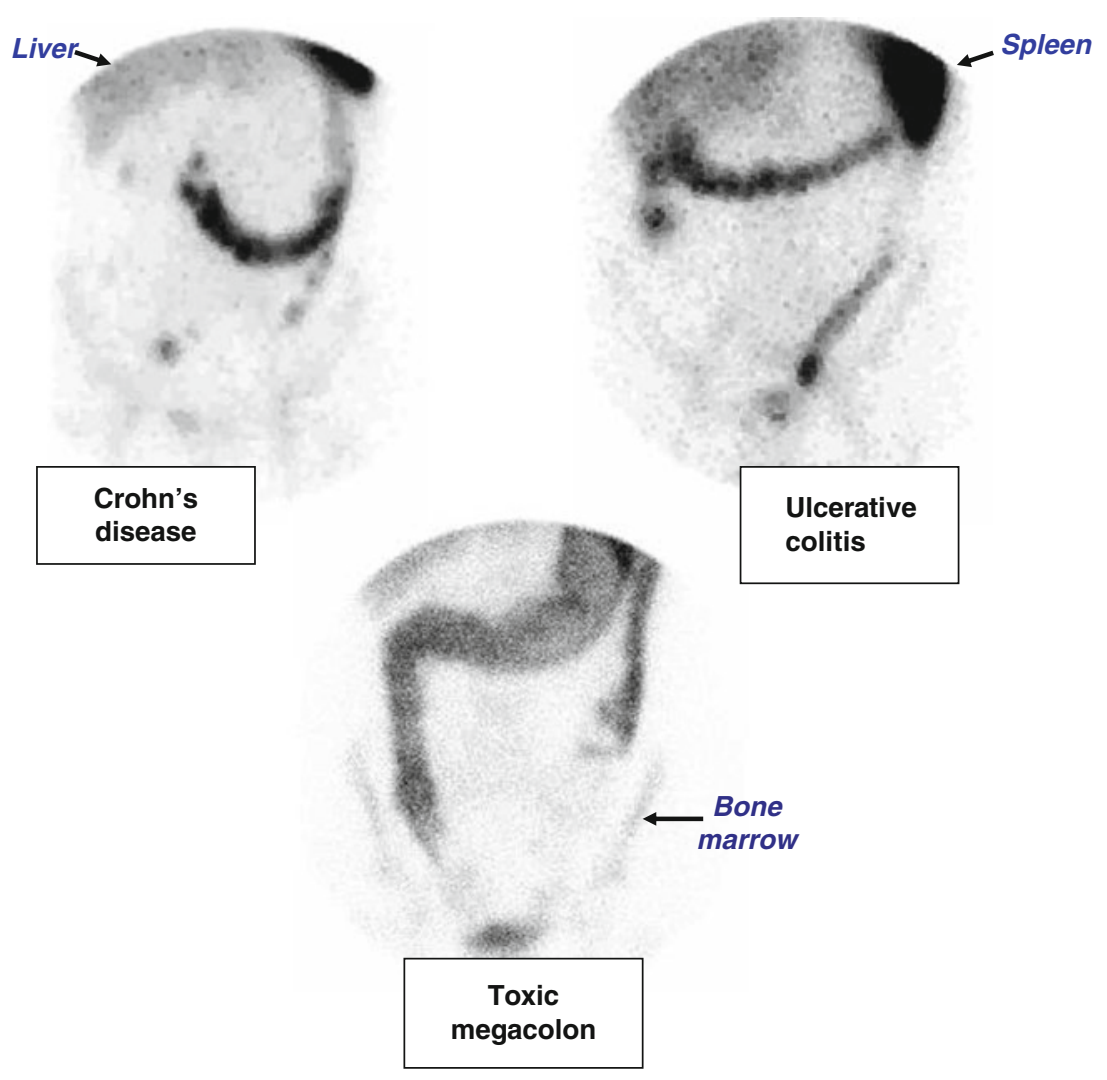

Fig. 12.4 Inflammatory bowel disease imaged $1 \mathrm{~h}$ after injection of Tc-99m-HMPAO-labelled leucocytes

granulocytes artificially activated by the labelling procedure and associated with very low intravascular recovery. This work led to quality control guidelines for leucocyte labelling.

Another major nuclear medicine landmark in the history of the Hammersmith radioisotope unit was the development by Mark Pepys and Philip Hawkins of I-123-labelled serum amyloid protein (SAP) for imaging amyloidosis [30]. This work was dramatically successful and led to the establishment of a separate unit in the hospital with its own gamma camera and technical staff, such was the weight of referrals from all over the country. So, at one time, there were five separate nuclear medicine units on the Hammersmith site! I remember Pepys and Hawkins opening champagne in the Radioisotope Unit when they had just witnessed heavy hepatic uptake of labelled SAP in a patient with amyloidosis (Fig. 12.5). I wondered if the celebrations might be premature, having learned that in general when a tracer is not functioning properly it is liable to end up in the liver, but this was clearly not the case!

The spirit of research collaboration at the Hammersmith Hospital fuelled many interesting research projects using radionuclides. For example, the early advances in 


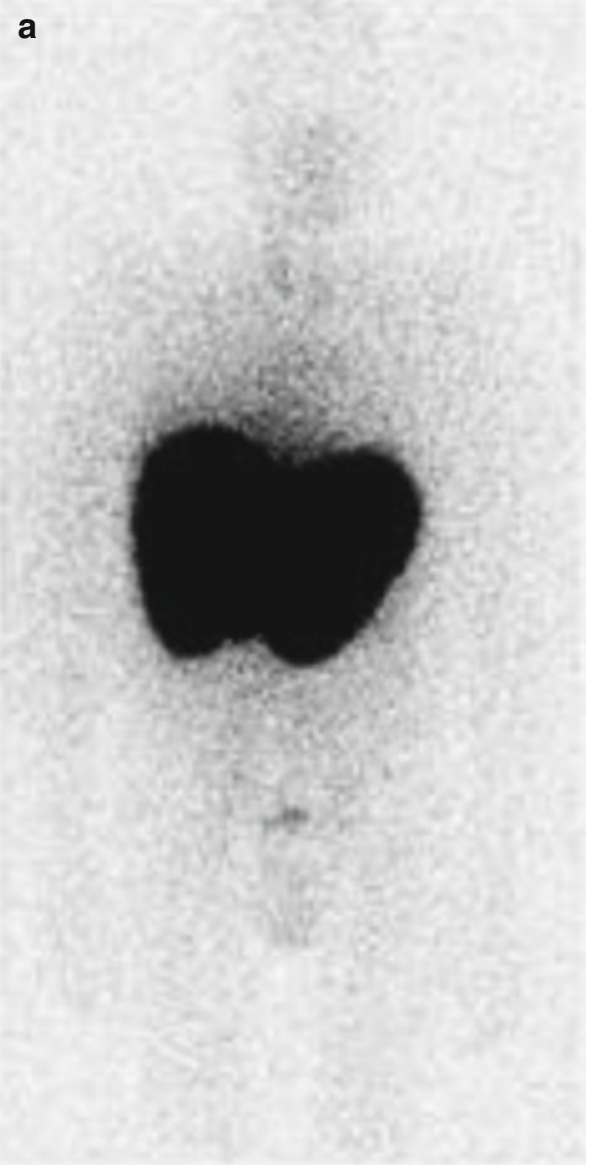

b

Fig. 12.5 Hepato-splenic amyloidosis (a) compared with normal distribution of I-123-labelled SAP (b) (From Refs. [29])

interventional radiology allowed us to inject In-111-labelled platelets directly into the splenic artery of patients having arterial catheterization and show conclusively that platelets pool in the spleen and are released after a mean residence time of about 10 min. Plasma exchange for the treatment of immune complex disease was shown to be associated with improved RE function as measured by the splenic extraction efficiency of radiolabelled antibody-coated red cells, using simultaneously injected In-111-labelled platelets to measure splenic blood flow [31]. Before then, it had been thought that RE function could be quantified by the clearance rate of heatdamaged red cells until we showed that the clearance rate reflected splenic pooling and was therefore, like platelet equilibration between blood and spleen, a measure of splenic blood flow. Early studies on pulmonary epithelial permeability using inhaled Tc-99m-DTPA [32] and pulmonary endothelial permeability using intravenous In-111-transferrin [33] were performed by Royston and his co-workers. Davies 
and Walport demonstrated for the first time the whole body kinetics of I-123labelled immune complexes [34].

In the mid-nineties, rotaPET was acquired by what had now been re-named the 'Nuclear Medicine Department'. This was a partial ring detector consisting of two separate segments and was used predominantly for FDG imaging of cancer but also clinical F-18-DOPA brain imaging. The department was involved in early clinical work with In-111-pentetriotide and showed how amino acid infusion blocked renal tubular uptake of the agent [35]. In research, Harrington and Stewart demonstrated the targeting of tumours by In-111-labelled stealth liposomes containing chemotherapeutic agents [36]. In collaboration with 'Tiny' Maini from the Institute of Rheumatology, the therapeutic effect of TNF $\alpha$ blockade was shown to reduce dramatically leucocyte uptake in rheumatoid joints [37]. Muhammad Mubashar was one of the first workers to image P-glycoprotein expression in breast cancer [38]. As one of the first centres in the UK to develop interventional radiology, the Hammersmith Hospital was a referral centre for conditions such as pulmonary arterio-venous shunts and much work with the Department of Respiratory Medicine [39] was performed to quantify these shunts before and after therapeutic embolization. Finally, elegant work performed in collaboration with George Hall, an anaesthetist with an interest in exercise physiology, demonstrated in trained athletes undergoing maximal brief exercise how platelets and all leucocyte subtypes pool in the spleen with similar residence times [40]. Contrasting the behaviour of red cells versus leucocytes and platelets in response to exercise, he showed that the spleen is essentially an erectile organ - permanently erect!

In the time I was at Hammersmith Hospital (1979-1999), the Hammersmith campus was probably the leading medical research hospital in the UK, and enjoyed a reputation based on a fantastic multidisciplinary approach and spirit of collaboration, co-operation and clinical support. Clinical research in nuclear medicine that goes beyond the evaluation of the latest novel radiopharmaceutical or imaging hardware critically depends on support from the clinicians, and this support was secondto-none at the Hammersmith.

Acknowledgements The author would like to thank Prof Mike Hughes and Prof Peter Lavender for advice regarding the work described in this article.

Open Access This chapter is distributed under the terms of the Creative Commons AttributionNoncommercial 2.5 License (http://creativecommons.org/licenses/by-nc/2.5/) which permits any noncommercial use, distribution, and reproduction in any medium, provided the original author(s) and source are credited.

The images or other third party material in this chapter are included in the work's Creative Commons license, unless indicated otherwise in the credit line; if such material is not included in the work's Creative Commons license and the respective action is not permitted by statutory regulation, users will need to obtain permission from the license holder to duplicate, adapt or reproduce the material. 


\section{References}

1. Glass HI, Hudson FR, French MT. A $70 \mathrm{~mm}$ diameter germanium detector medical radioisotope scanner. Medical Radioisotope Scintigraphy. Vienna: IAEA; 1973.

2. Fazio F, Jones T. Assessment of regional ventilation by continuous inhalation of radioactive krypton-81m. Br Med J. 1975;3(5985):673-6.

3. Turner JH, Selwyn AP, Jones T, et al. Continuous imaging of regional myocardial blood flow in dogs using krypton-81m. Cardiovasc Res. 1976;10:398-404.

4. Harf A, Pratt T, Hughes JMB. Regional distribution of VA/Q in man at rest and on exercise measured with krypton-81m. J Appl Physiol. 1978;44:115-23.

5. Amis TC, Jones HA, Hughes JMB. Effect of posture on interregional distribution of pulmonary perfusion and VA/Q ratios in man. Respir Physiol. 1984;56:169-82.

6. Ciofetta G, Silverman M, Hughes JMB. Quantitative approach to the study of regional lung function in children using Krypton-81m. Br J Radiol. 1980;53:950-9.

7. Lavender JP, Al-Nahhas AM, Myers MJ. Ventilation perfusion ratios of the normal supine lung using emission tomography. Br J Radiol. 1984;57:141-6.

8. Thakur ML, Lavender JP, Arnot RN, et al. Indium-111-labeled autologous leukocytes in man. J Nucl Med. 1977;18:1014-21.

9. Klonizakis I, Peters AM, Fitzpatrick ML, et al. Radionuclide distribution following injection of indium-111 labelled platelets. Br J Haematol. 1980;46:595-602.

10. West JB, Dollery CT. Distribution of blood flow and ventilation-perfusion ratio in the lung, measured with radioactive $\mathrm{CO}_{2}$. J Appl Physiol. 1960;15:405-10.

11. West JB, Dollery CT. Absorption of inhaled radioactive water vapour. Nature. 1961;189:588.

12. West JB, Dollery CT, Hugh-Jones P. The use of radioactive carbon dioxide to measure regional blood flow in the lungs of patients with pulmonary disease. J Clin Invest. 1961;40:1-12.

13. Jones T, Jones HA, Rhodes CG, et al. Distribution of extravascular fluid volumes in isolated perfused lungs measured with $\mathrm{H}_{2}{ }^{15} \mathrm{O}$. J Clin Invest. 1976;57:706-13.

14. Swinburne AJ, MacArthur CGC, Rhodes CG, et al. Measurement of lung water in dog lobes using inhaled $\mathrm{C}^{15} \mathrm{O}_{2}$ and injected $\mathrm{H}_{2}{ }^{15} \mathrm{O}$. J Appl Physiol Respir Environ Exercise Physiol. 1982;52:1535-44.

15. Ewan PW, Jones HA, Nosil J, et al. Uneven perfusion and ventilation within lung regions studied with nitrogen-13. Respir Physiol. 1976;34:45-60.

16. Ewan PW, Jones HA, Rhodes CG, et al. Detection of intrapulmonary haemorrhage with carbon monoxide uptake: application in Goodpasture's Syndrome. N Engl J Med. 1976;295:1391-6.

17. Valind SO, Rhodes CG, Brudin LH, et al. Measurements of regional ventilation pulmonary gas volume: theory and error analysis with special reference to positron emission tomography. J Nucl Med. 1991;32:1937-44.

18. Rhodes CG, Hughes JMB. Pulmonary studies using positron emission tomography. Eur Respir J. 1995;8:1001-17.

19. Jones HA, Clark RJ, Rhodes CG, et al. In vivo measurement of neutrophil activity in experimental lung inflammation. Am J Respir Crit Care Med. 1994;149:1635-9.

20. Jones HA. Inflammation imaging. Proc Am Thorac Soc. 2005;513-4:545-8.

21. Ueki J, Rhodes CG, Hughes JMB, et al. In vivo quantification of pulmonary beta-adrenoceptor density in man u sing S[ $\left.{ }^{11} \mathrm{C}\right] \mathrm{CGP} 12177$ and positron emission tomography. J Appl Physiol. 1993;75:559-65.

22. Hayes MJ, Qing F, Rhodes CG, et al. In vivo quantification of human pulmonary $\beta$-adrenoceptors with PET: effect of $\beta$-agonist therapy. Am J Resp Crit Care Med. 1996;154:1277-83.

23. Camici P, Araujo LI, Spinks T, et al. Increased uptake of ${ }^{18} \mathrm{~F}$-fluorodeoxyglucose in postischemic myocardium of patients with exercise-induced angina. Circulation. 1986;74:81-8.

24. Galasko CS, Westerman B, Sellwood RA, et al. Use of the gamma camera for early detection of osseous metastases from mammary cancer. Br J Surg. 1968;55:613-5. 
25. Peters AM, Lavender JP, Needham SG, et al. Imaging thrombus with a radiolabelled monoclonal antibody to platelets. Br Med J. 1986;293:1525-7.

26. Jamar F, Chapman PT, Harrison AA, et al. Inflammatory arthritis: imaging of endothelial cell activation with an In-111 labeled $\mathrm{F}\left(\mathrm{ab}{ }^{\prime}\right)_{2}$ fragment of anti-E-selectin monoclonal antibody. Radiology. 1995;194:843-50.

27. Peters AM, Saverymuttu SH, Reavy HJ, et al. Imaging inflammation with 111-indium tropolonate labeled leukocytes. J Nucl Med. 1983;24:39-44.

28. Peters AM, Danpure HJ, Osman S, et al. Preliminary clinical experience with Tc-99m-HMPAO for labelling leucocytes and imaging inflammation. Lancet. 1986;2:946-9.

29. Peters AM. Just how big is the pulmonary granulocyte pool? Clin Sci. 1998;94:7-19.

30. Hawkins PN, Myers MJ, Lavender JP, et al. Diagnostic radionuclide imaging of amyloid: biological targeting by circulating human serum amyloid P component. Lancet. 1988;1(8600):1413-8.

31. Walport MJ, Peters AM, Elkon KB, et al. The splenic extraction ratio of antibody coated erythrocytes and its response to plasma exchange and pulse methy-lprednisolone. Clin Exp Immunol. 1985;65:465-73.

32. Nolop KB, Maxwell DL, Fleming JS, et al. A comparison of ${ }^{99 \mathrm{~m}}$ Tc-DTPA and ${ }^{113 \mathrm{~m}} \mathrm{In}$-DTPA aerosol clearances in humans. Effects of smoking, hyperinflation and in vitro oxidation. Am Rev Respir Dis. 1987;136:1112-6.

33. Braude S, Nolop KB, Hughes JMB, et al. Comparison of lung vascular and epithelial permeability indices in the Adult Respiratory Distress Syndrome. Am Rev Respir Dis. 1986;133:1002-5.

34. Davies KA, Peters AM, Beynon HLC, et al. Immune complex processing in patients with sysytemic lupus erythematosus - in vivo imaging and clearance studies. J Clin Invest. 1992;90:2075-83.

35. Hammond PJ, Wade AF, Gwilliam ME, et al. Amino acid infusion blocks renal tubular uptake of an indium-labelled somatostatin analogue. Br J Cancer. 1993;67:1437-9.

36. Harrington KJ, Mohammadtaghi S, Uster PS, et al. Effective targeting of solid tumours in patients with locally advanced cancers by radiolabelled pegylated liposomes. Clin Cancer Res. 2001;7:243-54.

37. Taylor PC, Paleolog E, Chapman PT, et al. TNF $\alpha$ blockade in patients with rheumatoid arthritis reduces chemokines and leukocyte traffic to joints. Arthr Rheum. 2000;43:38-47.

38. Mubashar M, Harrington KJ, Chaudhary KS, et al. Tc-99m-sestamibi imaging in the assessment of toremifene as a modulator of multidrug resistance in patients with breast cancer. J Nucl Med. 2002;43:519-25.

39. Whyte MKB, Peters AM, Hughes JMB, et al. Quantification of right-to-left shunt at rest and during exercise in patients with pulmonary arteriovenous malformations. Thorax. 1992;47: 790-6.

40. Allsop P, Peters AM, Arnot RN, et al. Intrasplenic blood cell kinetics in man before and after brief maximal exercise. Clin Sci. 1992;83:47-54. 


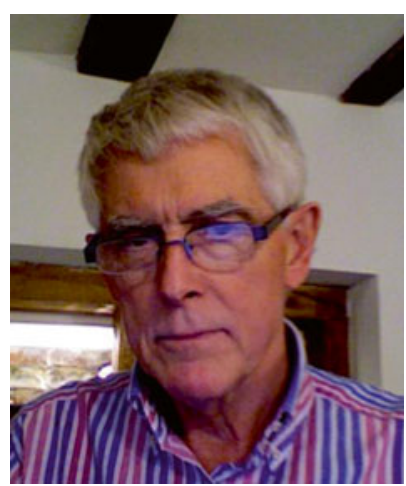

Michael Peters I did my pre-clinical training at St Mary's Hospital Medical School where I received a BSc in physiology in 1967. I then transferred to Liverpool University and received MB $\mathrm{ChB}$ in 1970. In 1972, I was appointed as lecturer in physiology in the medical school at Liverpool. This is where I discovered my interest in the use of radionuclides to study human physiology and did an MD in the use of Xenon-133 to measure hepatic perfusion. Uncertain of what I then wanted to do, I went to Australia and became a GP for 4 years, doing many different jobs and discovering the attractions of the country. I returned to England in 1978 a few weeks before my mother succumbed to breast cancer, and after a year in general practice in Liverpool 8 secured a clinical research fellowship at the Royal Postgraduate Medical School to work on In-111-labelled lymphocytes. There I met my mentor, Peter Lavender, and the great Robert Steiner. There followed 3 years of intense research on In-111 cell labelling and then the funding ran out so I joined Glaxo Group Research as a Research Physician. My big break came in 1984 when Isky Gordon and Peter Lavender created a senior lectureship in radiology split between RPMS and the Institute of Child Health. These two great functional radiologists convinced me of the importance of integrated imaging, a view later cemented by the introduction of PACS at the Hammersmith Hospital in the mid-nineties. In 1988, I became full time at RPMS and then, with Peter's retirement in 1991, ran nuclear medicine at Hammersmith single-handedly until 1999 when I was appointed Foundation Professor of Nuclear Medicine in Cambridge. At this time, Cambridge Medical School was growing rapidly under the leadership of Keith Peters, a man I greatly admired when he was Professor of Medicine at RPMS. I spent 6 productive years in Cambridge, working with Edwin Chilvers (respiratory medicine) and Arnie Purushotham (breast cancer), before moving to the new medical school in Brighton. The first appointments made in Brighton were Jon Cohen as Dean and Kevin Davies as Professor of Medicine, both ex Hammersmith colleagues, so whilst Cambridge was jokingly called Hammersmith North, Brighton became known as Hammersmith South. I should have retired 5 years ago but I am still working full-time and enjoying the research as much as ever. The three high points of my career were election to the fellowship of the Academy of Medical Sciences in 2002, award of a DSc from the University of Liverpool in 2009 and invitation to give the Annual Lecture at the spring meeting of the BNMS in Brighton in 2011. 